\title{
Impact Analysis of Trainings and Front Line Demonstrations in Black Gram (Vigna mungo) Cultivation of Tirap district of Arunachal Pradesh
}

\author{
Abhimanyu Chaturvedi ${ }^{*}$, Shashikant Chaturvedi ${ }^{2}$, Neha Sharma ${ }^{3}$, \\ T. S. Mishra ${ }^{4}$ and Shailendra Vikram Singh ${ }^{5}$ \\ ${ }^{1}$ Krishi Vigyan Kendra Tirap, Deomali, Arunachal Pradesh, India \\ ${ }^{2}$ Krishi Vigyan Kendra Lower Subansiri,Yachuli, Arunachal Pradesh, India \\ ${ }^{3}$ Krishi Vigyan Kendra Sagar, Madhya Pradesh, India \\ ${ }^{4}$ KVK West Kameng, Arunachal Pradesh, India \\ ${ }^{5}$ S.D.J.P.G.College-Chandeshwer-Azagmarh, Uttar Pradesh, India
}

*Corresponding author

Keywords

Adoption,

Integrated pest

management,

integrated nutrient

management,

Technology index

Article Info

Accepted:

25 August 2019

Available Online:

10 September 2019
The impact assessment for upgraded knowledge levels of farmers regarding scientific package of practices, extent of adoption of selected technology and percent adoption of production technology was carried out in 05 adopted villages. The data showed that Overall farmers knowledge level increased 8 (low level), 52 (medium level) and 28 (high level) per cent, respectively after intervention of Krishi Vigyan Kendra. The maximum knowledge regarding different scientific innovations was found for cultural practices $(48 \%)$, weed management $(41 \%)$, integrated nutrient management (35\%) pest and disease management (32 \%) and pest, IPM (2\%), respectively. The technology index depicted that there was feasibility of evolving technologies at the farmer's field.

\section{Introduction}

Black gram (Vigna mungo) is a widely grown pulse crop, belongs to the family fabaceae and having good importance for food and nutritional security in the world. Due to short duration crop; by nature and survivalist in all seasons either as sole or as intercrops. India is the world's largest producer as well as consumer of black gram. It produces about
1.5-1.9 MT of black gram annually from about $3.5 \mathrm{~m}$ ha of area, with an average productivity of $600 \mathrm{~kg} / \mathrm{ha}$. Black gram shares about 10 per cent of India's total pulse production. Therefore, it is necessary to assess the technological gap in production and also to know the problems and constraints in adopting modern black gram production technologies; Islam et al., (2011). Keeping all these in mind, the present investigation was carried out to 
find out the current knowledge level of black gram producers with following points: adoption scale of improved practices, yield gap etc.

\section{Materials and Methods}

The present study was conducted in Tirap district of Arunachal Pradesh during Kharif season of 2017-18. Twenty five farmers from 5 villages viz., Noitong, Nutan Basti, Lekhi Basti, Makat and Doidam were selected. The data were collected through personnel interview, tabulated and analyzed to find out the findings and draw the conclusion. The statistical tool like percentage was employed to analyze the data.

The constraints as perceived by respondents were scored on the basis of magnitude of the problem as per Meena and Sisodiya (2004). The responses were recorded and converted in to mean per cent score and ranked accordingly as per Warde et al.,(1991). The extension gap, technology gap and the technology index were work out with the help of formulas given by Samui et al., (2000) as mentioned below:

Extension gap $=$ Demonstration yieldfarmers' yield (control)

Technology gap $=$ Potential yielddemonstration yield

Technology index

Technology gap

Potential Yield

\section{Results and Discussion}

The result revealed that the overall knowledge about black gram cultivation before intervention by the KVK was $44,38,9$ per cent (low, level, medium level high level), respectively which was positively changed up to 08,52 and 28 per cent, after intervention of
KVK through different training programmes, kisan gosthis, field visits and front line demonstrations (FLDs) (Table 1). The similar findings reported by earlier researchers: Javat et al., (2011) and Das et al., (2010).

In respect to different aspects of scientific cultivation of black gram; the total $48 \%$ of farmers were possessing high level of knowledge regarding cultural practice followed by weed management (41\%), integrated nutrient management (35\%). While the minimum knowledge were possessed about IPM (25\%) and pest, disease control (32\%) (Table 2).

Before intervention of the KVK, the total $48 \%$ of farmers had medium level of knowledge; which was drastically changed after intervention of KVK (71 per cent of the farmers had high level of knowledge regarding scientific cultivation of black gram) (Table 3 ). In the case of adoption per cent of different technologies; the Cultural practices segment scored highest adoption percentage (64\%) followed by pest and disease control (59\%), IPM $(56 \%)$ respectively, while the minimum adoption per cent was recorded with INM (47\%) followed by Weed management $(53 \%)$ (Table 4).

\section{Yield gap analysis of black gram cultivation}

Table 5 clearly showing that the maximum yield $(7.76 \mathrm{q} / \mathrm{ha}$ ) was reported in FLD plots and minimum yield $(5.4 \mathrm{q} / \mathrm{ha})$ under farmers' plots. The cost benefit ratio was higher in FLD plot (1:3.35) than control (1: 2.48). These findings are clearly showing that due to knowledge and adoption of scientific practices, the yield of black gram could be increased by 37 per cent, 19 per cent and 40 per cent over the yield obtained under farmers' practices. These findings are supported by findings of Dubey et al., (2010). 
Table.1Overall knowledge of scientific package of practices of blackgram.

\begin{tabular}{|l|c|c|}
\hline Category & Before intervention of KVK & After intervention of KVK \\
\hline Low level of knowledge & 44 & 08 \\
\hline Medium level of knowledge & 38 & 52 \\
\hline High level of knowledge & 9 & 28 \\
\hline
\end{tabular}

Table.2 Knowledge regarding different technologies for black gram cultivation.

\begin{tabular}{|l|l|l|l|l|}
\hline Sr. & Technology & Low & Medium & High \\
\hline $\mathbf{1}$ & Cultural Practices & 36 & 16 & 48 \\
\hline $\mathbf{2}$ & Pest and disease control & 25 & 43 & 32 \\
\hline $\mathbf{3}$ & Integrated pest management & 34 & 41 & 25 \\
\hline $\mathbf{4}$ & Weed management & 21 & 38 & 41 \\
\hline $\mathbf{5}$ & Integrated nutrient management & 26 & 39 & 35 \\
\hline
\end{tabular}

Table.3 Overall adoption of scientific package of practices of blackgram (percentage)

\begin{tabular}{|l|c|c|}
\hline Category & Before intervention of KVK & After intervention of KVK \\
\hline Low level of knowledge & 26 & 7 \\
\hline Medium level of knowledge & 48 & 22 \\
\hline High level of knowledge & 26 & 71 \\
\hline
\end{tabular}

Table.4 Adoption of Technologies

\begin{tabular}{|l|l|l|}
\hline S.No. & Name of Technology & Adoption \% \\
\hline $\mathbf{1}$ & Cultural practices & 64 \\
\hline $\mathbf{2}$ & Pest \& Disease management & 59 \\
\hline $\mathbf{3}$ & Integreted Pest Management & 56 \\
\hline $\mathbf{4}$ & Weed management & 53 \\
\hline $\mathbf{5}$ & Integreted Nutrient Management & 47 \\
\hline
\end{tabular}

Table.5 Productivity, Yield gaps and Technology Index of Black gram

\begin{tabular}{|c|c|c|c|c|c|c|c|c|c|c|}
\hline \multirow[t]{2}{*}{ Year } & \multirow{2}{*}{$\begin{array}{c}\text { Area } \\
\text { (ha) }\end{array}$} & \multirow{2}{*}{$\begin{array}{c}\text { No of } \\
\text { Demos. }\end{array}$} & \multicolumn{2}{|c|}{ Yield (q/ha) } & \multirow{2}{*}{$\begin{array}{c}\text { Per cent } \\
\text { Increase } \\
\text { in yield }\end{array}$} & \multicolumn{2}{|c|}{ B:C ratio } & \multirow{2}{*}{$\begin{array}{l}\text { Extension } \\
\text { gap (q/ha) }\end{array}$} & \multirow{2}{*}{$\begin{array}{l}\text { Technology } \\
\text { gap (q/ha) }\end{array}$} & \multirow{2}{*}{$\begin{array}{l}\text { Technology } \\
\text { Index }\end{array}$} \\
\hline & & & Demos & Control & & Demos & Control & & & \\
\hline 2016 & 10 & 24 & 6.58 & 4.80 & 37 & 3.26 & 2.67 & 1.78 & 3.24 & 32.99 \\
\hline 2017 & 10 & 25 & 7.93 & 6.39 & 19 & 2.96 & 2.48 & 1.54 & 1.89 & 19.24 \\
\hline \multirow[t]{2}{*}{2018} & 10 & 25 & 8.77 & 5.26 & 40 & 3.84 & 2.30 & 3.51 & 1.05 & 10.69 \\
\hline & \multicolumn{2}{|c|}{ Average } & 7.76 & 5.48 & 32 & 3.35 & 2.48 & 2.27 & 2.06 & 20.97 \\
\hline
\end{tabular}


Int.J.Curr.Microbiol.App.Sci (2019) 8(9): 2881-2886
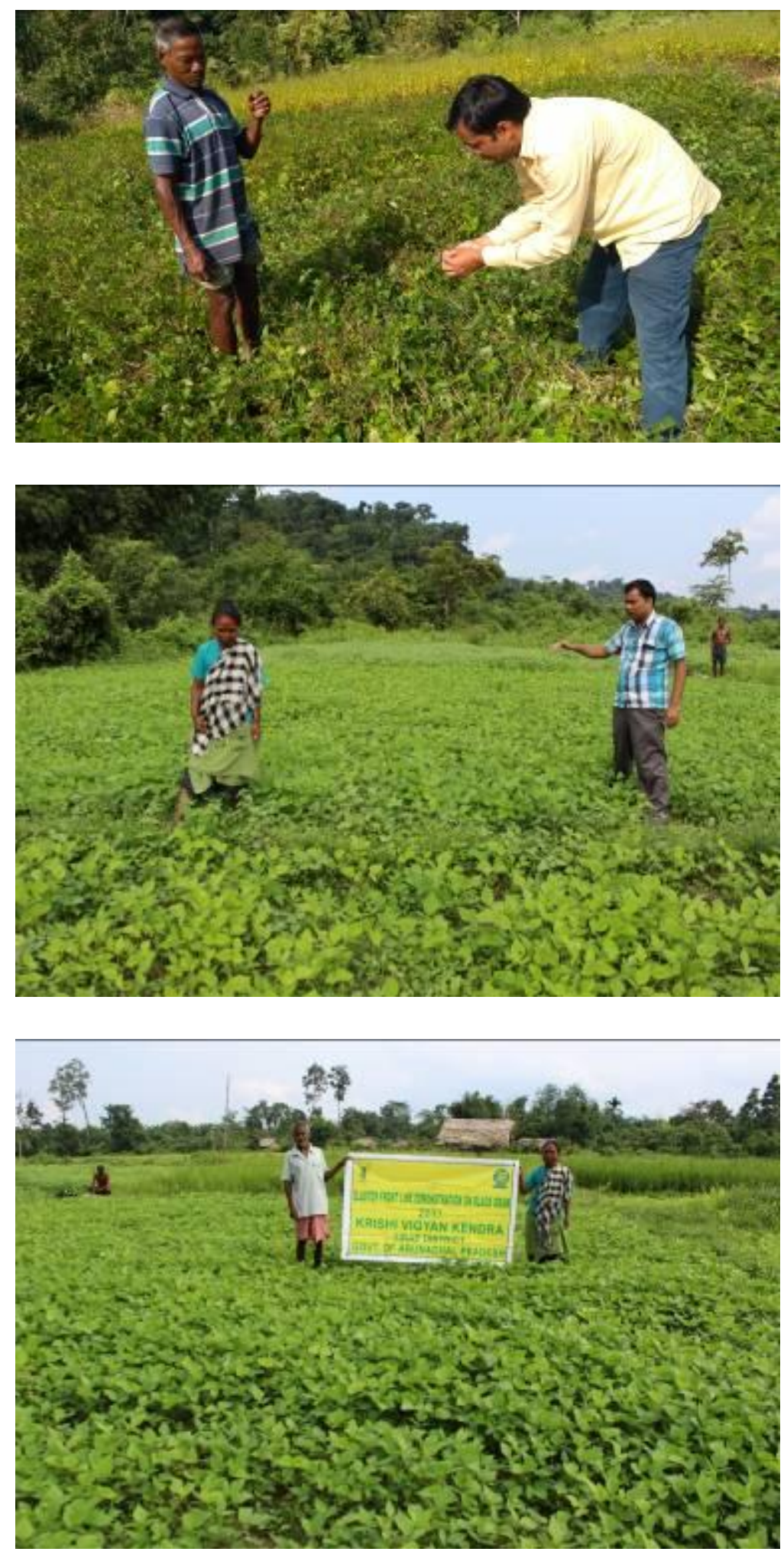


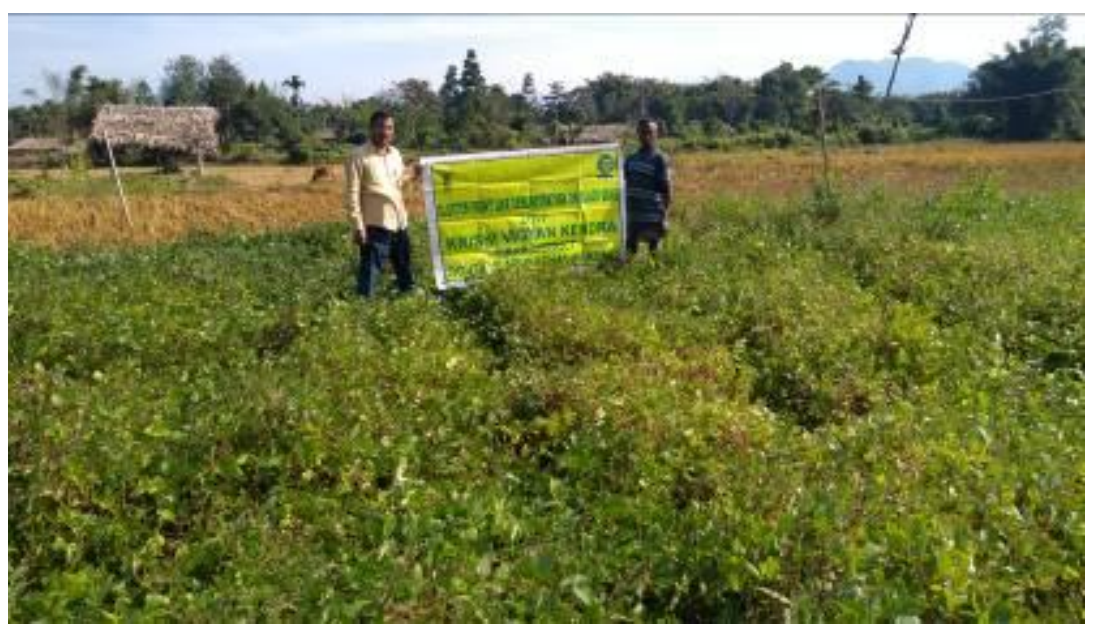

The yield of the front line demonstration trials and potential yield of the crop was compared to estimate the yield gaps which were further categorized into technology and extension gaps (Hiremath and Nagaraju, 2009).

The average extension gap was $2.27 \mathrm{q} / \mathrm{ha}$, which indicates the better and intensive education of farmers through different means like FLD, trainings, kisan gosthi, field visits etc. The average technology gap was $2.06 \mathrm{q} / \mathrm{ha}$ (ranged between $1.05 \mathrm{q} / \mathrm{ha}$ to $3.24 \mathrm{q} / \mathrm{ha}$ ). The average technology gap from three year of FLDs programme was $25 \mathrm{q} / \mathrm{ha}$. The variation of technology gap observed may be soil fertility status, followed agricultural practices and micro climatic conditions.

Technology index showed that huge gap between farmer's field and demonstration field. There are huge scopes of scientific technologies at the farmer field. Lower the value of technology index, more is the feasibility of technology demonstrated, (Sagar and Chandra, 2004; Arunachalam, 2011 and Kumar et al., 2014).

The reduction of technology index from 32.99 per cent (2016) to 10.69 per cent (2018) exhibited the feasibility of technology demonstrated. Similarly, the yield enhancement in different crops in front line demonstration has amply been documented by
Haque (2000), Mishra et al., (2009) and Kumar et al., (2010).

The FLD proved a significant positive results with motivation to researcher for further demonstration of productivity potential and profibility at farmers field. Similar finding were reported by Kirar et al., (2005) and Chauhan and Pandya (2012) in gram.

The scientific knowledge level and adoption level of different technologies on black gram cultivation were positively changed; in five adopted villages after imparting training, FLD, kisan gosthi, field visits, by KVK scientists in Tirap district of Arunachal Pradesh.

The higher productivity recorded under FLD over farmers practices created awareness and also encouraged the other farmers to adopt scientific know how for blackgram cultivation e.i., cultural practices, integrated pest management, integrated nutrient management, integrated weed management etc. in the district.

\section{Acknowledgement}

Krishi Vigyan Kendra, Tirap is thankful to the Director, ICAR-ATARI, Zone-VI, Guwahati for providing funds for conducting the CFLDs and farmers who always show faith in the Krishi Vigyan Kendra. 


\section{References}

Arunachalam R (2011). Spread and acceptance of recommended production technologies in green gram and black gram: a comparative analysis. Legume Res - An Int J 34(1):8-13

Chauhan N M and Pandya C D (2012). Impact and yield crack analysis of trainings and FLDs regarding scientific practices of Gram. Agric Update 7(3\&4): 199-202.

Das Mamoni, Puzari N N and Ray B K (2010).Impact of training of skill and knowledge development of rural women. Agric Extn Rev 1(1): 29-30.

Dubey S, Tripathi S, Singh P and Sharma R K (2010). Yield gap analysis of black gram production through frontline demonstration. J Prog Agric 1(1): 42-44.

Haque M S (2000). Impact of compact block demonstration on increase in productivity of rice. Maharashtra J Extn Edu 19 (1): 22-27.

Hiremath S M and Nagaraju M V (2009). Evaluation of front line demonstration trials on onion in Haveri district of Karnataka. Karnataka J Agric Sci 22 (5):1092-1093

Islam M, Mohanty A K and Kumar S (2011). Correlation growth yield and adoption of urdbean technologies. Indian Res J Ext Edu 11 (2): 20-24.

Javat H, Patel M M, Kumar K S and Saxena $A$ (2011).Impact of front line demonstrations on scientific temperament of wheat growers Rajasthan J Extn Edu.
17-18:115- 117.

Kirar B S, Mahajan S K, Nshine R, Awasthi H K and Shukla R N (2005). Impact of technological practices on the productivity of soybean in front line demonstration. Indian Res $J$ Extn Edu 5 (1):15-17.

Kumar A, Kumar R, Yadav V P S and Kumar R (2010). Impact assessment of Frontline demonstrations of Bajra in Haryana State. Indian Res J Extn Edu 10(1): 105-108.

Kumar S, Singh R and Singh A (2014). Assessment of gaps in pulse production in Hamipur district of Himachal Pradesh. Indian Res J Ext Edu 14 (2): 20-24

Meena S R and Sisodiya S S (2004). Constraints as perceived by the respondents in adoption of recommended guava production technology. Rajasthan $J$ Extn Edu 12-13:146- 153.

Mishra D K, Paliwal D K, Tailor R S and Deshwal A K (2009). Impact of Frontline demonstrations on yield enhancement of potato. Indian Res J Extn Edu 9 (3): 2628.

Sagar R L and Chandra G (2004). Frontline demonstration on sesame in West Bengal. Agric Extn Rev 16 (2):7-10.

Samui S K, Maitra S, Roy D K, Mandal A K and Saha D (2000). Evaluation of frontline demonstration on groundnut. $J$ Indian Soc Costal Agric Res 18 (2):180183.

Warde P N, Bhope R S and Chudhary D P (1991). Adoption of dry land horticulture technology. Maharastra J Extn Edu 10 (2): 108-111.

\section{How to cite this article:}

Abhimanyu Chaturvedi, Shashikant Chaturvedi, Neha Sharma, T. S. Mishra and Shailendra Vikram Singh 2019. Impact Analysis of Trainings and Front Line Demonstrations in Black Gram (Vigna mungo) Cultivation of Tirap district of Arunachal Pradesh. Int.J.Curr.Microbiol.App.Sci. 8(09): 2881-2886. doi: https://doi.org/10.20546/ijcmas.2019.809.331 